\title{
Recent Experience and Future Prospects of Pakistan's Trade with China
}

\author{
Musleh-ud Din*, Ejaz Ghani** and Usman Qadir ${ }^{* * * *}$
}

\begin{abstract}
This paper examines the prospects of expanding bilateral trade between Pakistan and China particularly in the context of the recently signed free trade agreement between the two countries. Using the augmented gravity model in the tradition of Rose (2004), the paper shows that there is significant potential for the expansion of bilateral trade between the two countries as a result of the free trade agreement. The paper also analyzes bilateral trade flows between the two countries in terms of a trade specialization index and the Grubel-Lloyd index of intraindustry trade. We show that bilateral trade between the two countries is heavily tilted in favor of China and that this situation may persist in the short term.
\end{abstract}

JEL Classification: E23, F10, 040.

Keywords: Pakistan, bilateral trade, growth.

\section{Introduction}

Like many developing economies, Pakistan has considerably liberalized its trade regime with a view to improving its growth prospects through greater trade and investment. In this context, Pakistan has actively pursued a policy of enhancing bilateral and regional economic cooperation. Of particular interest to Pakistan are its trade relations with neighboring China with which it has enjoyed a long lasting friendship underpinned by mutual cooperation and partnership in various socioeconomic and technical fields. In their desire to further strengthen trade and economic cooperation, both countries signed a comprehensive free trade agreement (FTA) in 2006.

This paper examines the experience of trade relations between Pakistan and China and explores the future prospects of bilateral trade

\footnotetext{
* Chief of Research, Pakistan Institute of Development Economics, Islamabad.

${ }^{* *}$ Chief of Research, Pakistan Institute of Development Economics, Islamabad.

${ }^{* * *}$ Research Economist, Pakistan Institute of Development Economics, Islamabad.
} 
between the two countries particularly in the context of the recently signed free trade agreement. In particular, we utilize a gravity model to assess the potential impact of the Pakistan-China free trade agreement on bilateral trade flows between the two countries. To explore the potential areas of bilateral trade, the analysis is complemented by the computation of two widely used trade indices, i.e., the trade specialization index and the Gruble-Lloyd index of intra-industry trade.

Section 2 provides an overview of trade flows between China and Pakistan. Section 3 lays out the specifications of the gravity model, and Section 4 reports the results of estimation. Section 5 analyzes bilateral trade flows between Pakistan and China in terms of the trade specialization index, whereas Section 6 examines the pattern of intra-industry trade in terms of the Gruble-Lloyd index. Section 7 concludes the discussion.

\section{Overview of Pakistan-China Trade Relations}

\subsection{Bilateral Trade Flows}

China has now become Pakistan's major trading partner, accounting for roughly one fifth of Pakistan's total trade in 2006. Pakistan's trade with China increased from US\$794.76 million in 2000 to US\$3,421.57 in 2006, thanks to strong domestic demand and a pickup in investment spending that led to a surge in imports from China (Table-1). Although bilateral trade with China has increased over the years, it remains concentrated in a few commodities. In 2006, machinery and transport equipment (the bulk of which comprised telecommunications equipment and general industrial machinery) and manufactured products (made up of textile yarn and fabrics, and iron and stee1), respectively, accounted for 48 and $24 \%$ of Pakistan's total imports from China (Table-2). Pakistan's exports to China were dominated by textile yarn, fabrics, and made-up articles, which together accounted for nearly $78 \%$ of total exports to China (Table-3).

The composition of bilateral trade between the two countries has undergone a shift from primary to finished goods in the case of Pakistan's imports from China, and from primary to semi-finished goods in the case of China's imports from Pakistan. For example, the share of food and live animals, which constituted 33\% of Pakistan's imports from China in 1990, decreased to about $3 \%$ in 2004 . On the other hand, the share of machinery and transport equipment in Pakistan's total imports from China increased from $28 \%$ in 1990 to $45 \%$ in 2004. In terms of Pakistan's exports to China, the share of crude materials fell from $75 \%$ in 1990 to only $11 \%$ in 2004 whereas the share of semi-manufactures increased from a meager $2 \%$ to about $74 \%$ during the same period. 
Table-1: Pakistan's Bilateral Trade with China

\begin{tabular}{crrrr}
\hline Period & Exports & Share & Imports & Share \\
\hline 1990 & 66.91 & $1.20 \%$ & 336.68 & $4.58 \%$ \\
1991 & 61.36 & $0.94 \%$ & 358.44 & $4.23 \%$ \\
1992 & 54.12 & $0.74 \%$ & 420.78 & $4.49 \%$ \\
1993 & 59.97 & $0.87 \%$ & 436.59 & $4.48 \%$ \\
1995 & 121.16 & $1.49 \%$ & 515.26 & $4.40 \%$ \\
1996 & 118.88 & $1.28 \%$ & 574.27 & $4.73 \%$ \\
1997 & 158.20 & $1.81 \%$ & 584.80 & $5.04 \%$ \\
1998 & 154.96 & $1.82 \%$ & 422.75 & $4.54 \%$ \\
1999 & 180.72 & $2.16 \%$ & 446.76 & $4.40 \%$ \\
2000 & 244.65 & $2.66 \%$ & 550.11 & $4.97 \%$ \\
2001 & 289.38 & $3.13 \%$ & 487.02 & $4.78 \%$ \\
2002 & 236.37 & $2.39 \%$ & 698.54 & $6.29 \%$ \\
2003 & 259.64 & $2.18 \%$ & 957.33 & $7.34 \%$ \\
2004 & 300.58 & $2.25 \%$ & $1,488.77$ & $8.29 \%$ \\
2005 & 435.68 & $2.71 \%$ & $2,349.39$ & $9.36 \%$ \\
2006 & 506.64 & $2.99 \%$ & $2,914.93$ & $9.77 \%$ \\
\hline
\end{tabular}

Source: UN COMTRADE Database - online access.

Figure 1: Bilateral Trade Growth Rates: 1991-2005

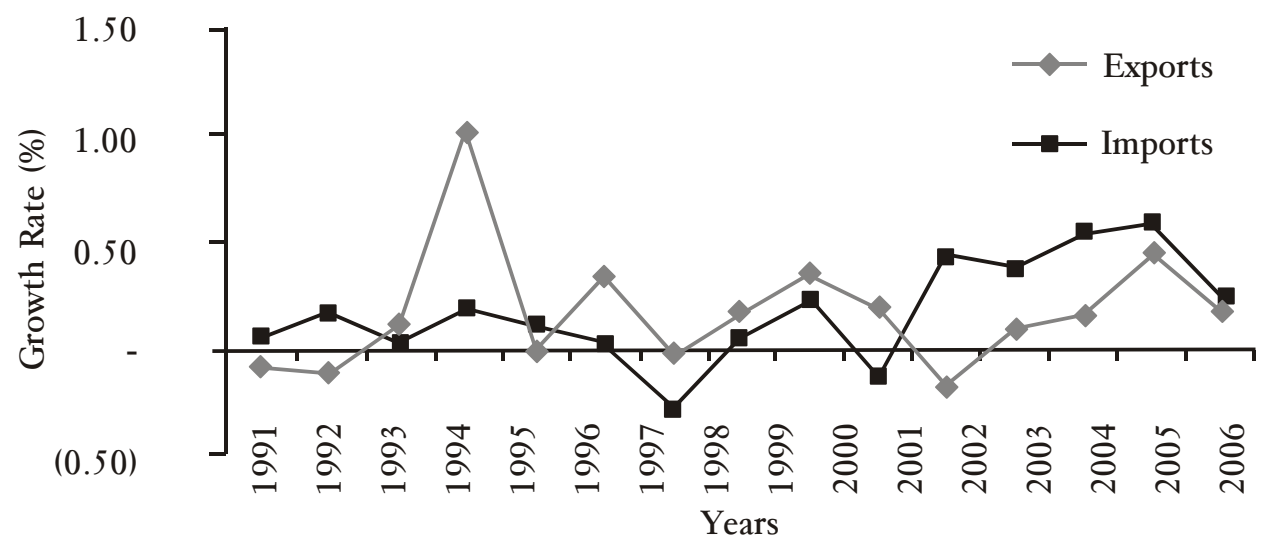

Source: Authors' calculations based on UNCOMTRADE database.

An analysis of commodity shares in bilateral trade reveals that, while Pakistan's exports to China are dominated by the textiles sector (Table-5), Pakistan imports a wide variety of products from China. Machinery, 
mechanical appliances, and electrical equipment have the highest share in China's exports to Pakistan, accounting for about 38\% of China's exports to Pakistan in 2006 (Table-4). In addition, such products as textiles and garments, chemical products, and rubber and plastic products are also significant in China's exports to Pakistan. The two product categories of manmade filaments (HS 54) and knitted or crocheted apparel (HS 61) accounted for about $9 \%$ of Chinese exports to Pakistan, while organic chemicals and miscellaneous chemical products accounted for 6\%. Rubber products (HS 40) and plastic products (HS 39) accounted for 5\%. Miscellaneous goods, which accounted for 5.9\%, consisted of tourist purchases by Pakistani citizens in China.

China's exports to Pakistan are much more diversified than Pakistan's exports to China, indicative of the fact that China has captured a wider exports market while Pakistan has traditionally focused on a limited range of primary and semi-manufactured exports. The top ten product categories accounted for $65 \%$ of China's exports to Pakistan (Table-4) while the top ten product categories accounted for almost 95\% of Pakistan's exports to China (Table-5). In fact, the top five product categories alone accounted for over 90\% of Pakistan's exports to China.

\subsection{China-Pakistan Free Trade Agreement}

To strengthen trade and investment linkages, Pakistan and China have signed a comprehensive Free Trade Agreement (FTA) covering trade in goods and services, bilateral investment, and institutional mechanisms for supporting bilateral trade and investment. The FTA follows the Early Harvest Program between the two countries under which tariff reductions have been implemented on Chinese and Pakistani products in over 3,000 tax items since January $1^{\text {st }} 2006$. 
Table-2: Commodity-wise Bilateral Trade of Pakistan with China Imports

\begin{tabular}{|c|c|c|c|c|c|c|c|c|}
\hline \multirow{2}{*}{$\begin{array}{l}\text { Product } \\
\text { Category }\end{array}$} & \multicolumn{2}{|c|}{1990} & \multicolumn{2}{|c|}{1998} & \multicolumn{2}{|c|}{2004} & \multicolumn{2}{|c|}{2006} \\
\hline & Value & Share & Value & Share & Value & Share & Value & Share \\
\hline \multicolumn{9}{|l|}{ Imports } \\
\hline Total & 336.68 & 100.00 & 422.75 & 100.00 & $1,488.77$ & 100.00 & $2,914.93$ & 100.00 \\
\hline $\begin{array}{l}\text { Machinery and } \\
\text { transport } \\
\text { equipment }\end{array}$ & 94.49 & 28.07 & 142.97 & 33.82 & 677.73 & 45.52 & $1,393.10$ & 47.79 \\
\hline $\begin{array}{l}\text { Manufactured } \\
\text { goods classified } \\
\text { chiefly by } \\
\text { materials }\end{array}$ & 54.42 & 16.16 & 71.24 & 16.85 & 275.23 & 18.49 & 702.61 & 24.10 \\
\hline $\begin{array}{l}\text { Chemicals and } \\
\text { related } \\
\text { products, nes }\end{array}$ & 59.99 & 17.82 & 155.97 & 36.89 & 327.79 & 22.02 & 394.28 & 13.53 \\
\hline $\begin{array}{l}\text { Miscellaneous } \\
\text { manufactured } \\
\text { articles }\end{array}$ & 6.96 & 2.07 & 20.91 & 4.95 & 93.32 & 6.27 & 188.35 & 6.46 \\
\hline $\begin{array}{l}\text { Mineral fuels, } \\
\text { lubricants and } \\
\text { related } \\
\text { materials }\end{array}$ & 4.14 & 1.23 & 4.12 & 0.97 & 54.18 & 3.64 & 113.97 & 3.91 \\
\hline $\begin{array}{l}\text { Food and live } \\
\text { animals chiefly } \\
\text { for food }\end{array}$ & 112.28 & 33.35 & 23.37 & 5.53 & 43.28 & 2.91 & 94.36 & 3.24 \\
\hline $\begin{array}{l}\text { Crude } \\
\text { materials, } \\
\text { inedible, except } \\
\text { fuels }\end{array}$ & 3.88 & 1.15 & 3.50 & 0.83 & 13.65 & 0.92 & 24.88 & 0.85 \\
\hline $\begin{array}{l}\text { Commodities } \\
\text { and transactions } \\
\text { not classified } \\
\text { elsewhere in } \\
\text { the SITC }\end{array}$ & 0.15 & 0.04 & 0.51 & 0.12 & 2.70 & 0.18 & 2.64 & 0.09 \\
\hline $\begin{array}{l}\text { Animal and } \\
\text { vegetable oils, } \\
\text { fats and waxes }\end{array}$ & 0.38 & 0.11 & 0.15 & 0.04 & 0.66 & 0.04 & 0.69 & 0.02 \\
\hline $\begin{array}{l}\text { Beverages and } \\
\text { tobacco }\end{array}$ & - & 0.00 & 0.01 & 0.00 & 0.24 & 0.02 & 0.04 & 0.00 \\
\hline
\end{tabular}

Source: UN COMTRADE Database. 
Table-3: Commodity-wise Bilateral Trade of Pakistan with China Exports

(US \$ Millions)

\begin{tabular}{lccccccccc}
\hline \multirow{2}{*}{ Product Category } & \multicolumn{2}{c}{1990} & \multicolumn{2}{c}{1998} & \multicolumn{2}{c}{2004} & \multicolumn{2}{c}{2006} \\
\cline { 2 - 9 } & Value & Share & Value & Share & Value & Share & Value & Share \\
\hline Exports & 66.91 & 100.00 & 154.96 & 100.00 & 00.58 & 100.00 & 06.64 & 100.00 \\
Total & 1.62 & 2.42 & 126.59 & 81.70 & 23.72 & 74.43 & 393.04 & 77.58 \\
$\begin{array}{l}\text { Manufactured goods } \\
\text { classified chiefly by } \\
\text { materials }\end{array}$ & & & & & & & & \\
$\begin{array}{l}\text { Crude materials, } \\
\text { inedible, except fuels }\end{array}$ & 50.18 & 74.99 & 9.86 & 6.36 & 32.30 & 10.75 & 54.87 & 10.83 \\
$\begin{array}{l}\text { Food and live animals } \\
\text { chiefly for food }\end{array}$ & 0.01 & 0.01 & 11.90 & 7.68 & 24.56 & 8.17 & 29.18 & 5.76 \\
$\begin{array}{l}\text { Chemicals and related } \\
\text { products, nes }\end{array}$ & 0.01 & 0.02 & 0.20 & 0.13 & 10.45 & 3.48 & 20.12 & 3.97 \\
$\begin{array}{l}\text { Miscellaneous } \\
\text { manufactured articles }\end{array}$ & 0.13 & 0.19 & 0.47 & 0.30 & 6.28 & 2.09 & 7.05 & 1.39 \\
$\begin{array}{l}\text { Machinery and } \\
\text { transport equipment }\end{array}$ & 0.14 & 0.22 & 2.86 & 1.85 & 2.82 & 0.94 & 2.24 & 0.44 \\
$\begin{array}{l}\text { Commodities and } \\
\text { transactions not } \\
\text { classified elsewhere in } \\
\text { the SITC }\end{array}$ & 0.46 & 0.68 & 0.01 & 0.00 & 0.33 & 0.11 & 0.14 & 0.03 \\
$\begin{array}{l}\text { Animal and vegetable } \\
\text { oils, fats and waxes }\end{array}$ & 14.37 & 21.47 & 3.07 & 1.98 & 0.01 & 0.00 & 0.00 & 0.00 \\
$\begin{array}{l}\text { Beverages and } \\
\text { tobacco }\end{array}$ & - & 0.00 & - & 0.00 & 0.10 & 0.03 & - & 0.00 \\
\hline
\end{tabular}

Source: UN COMTRADE Database. 
Table-4: Share of Top 10 Product Categories in China's Exports to Pakistan

\begin{tabular}{clrr}
\hline HS Code & Commodity & $\mathbf{2 0 0 0}$ & $\mathbf{2 0 0 6}$ \\
\hline 84 & Nuclear reactors, boilers, machinery, etc & 18.59 & 18.39 \\
85 & Electrical, electronic equipment & 10.22 & 15.40 \\
54 & Manmade filaments & 1.36 & 8.94 \\
99 & Commodities not specified according to kind & 6.68 & 5.25 \\
72 & Iron and steel & 3.23 & 3.40 \\
87 & Vehicles other than railway, tramway & 2.01 & 3.34 \\
29 & Organic chemicals & 5.89 & 3.18 \\
61 & Articles of apparel, accessories, knit or crochet & 0.60 & 3.01 \\
73 & Articles of iron or steel & 2.28 & 2.90 \\
40 & Rubber and articles thereof & 3.10 & 2.51 \\
Total & All Commodities & 53.97 & 66.30 \\
\hline
\end{tabular}

Source: UNCOMTRADE Database website.

Table-5: Share of Top Ten Product Categories in Pakistan's Exports to China

\begin{tabular}{clrr}
\hline $\begin{array}{c}\text { HS 2002 } \\
\text { Code }\end{array}$ & \multicolumn{1}{c}{ Commodity } & 2000 & 2006 \\
\hline 52 & Cotton & 80.95 & 70.70 \\
41 & Raw hides and skins (other than fur skins) and & 3.81 & 6.19 \\
& $\begin{array}{l}\text { leather } \\
26\end{array}$ & & \\
03 & Ores, slag and ash & 1.85 & 5.49 \\
& Fish and crustaceans, mollusks, and other & 1.69 & 4.86 \\
29 & aquatic invertebrates & & \\
74 & Organic chemicals & 4.87 & 3.23 \\
39 & Copper and articles thereof & 0.06 & 1.49 \\
12 & Oil seeds and oleaginous fruits & 0.85 & 1.02 \\
13 & Lac; gums, resins and other vegetable saps & 0.00 & 0.78 \\
& and extracts & 0.05 & 0.64 \\
16 & Preparations of meat, fish, or crustaceans & 0.00 & 0.48 \\
TOTAL & ALL COMMODITIES & 94.13 & 94.89 \\
\hline
\end{tabular}

Source: UNCOMTRADE Database website. 
The FTA that came into force on 1 July 2007 envisaged a phased and gradual program of elimination of tariffs on substantially all bilateral trade covering Chapters 1-97 of the Harmonized System (HS). For both the countries, tariff reductions or eliminations for the first phase were to be completed within a period of five years, i.e., by 1 January 2012. In the case of Pakistan, for the first phase the FTA provides for six different categories of tariff reduction modalities as follows (Table-6): elimination of tariffs within three years (I); duties reduced to $5 \%$ or below within five years (II); duties reduced by a margin of preference of $50 \%$ within five years (III); duties reduced by a margin of preference of $20 \%$ within five years (IV); no concession (V); and excluded (VI). For China, for the first phase, five categories are foreseen: elimination of tariffs within three years (I); duties reduced to $5 \%$ or below within five years (II); duties reduced by a margin of preference of $50 \%$ within five years (III); duties reduced by a margin of preference of $20 \%$ within five years (IV); and no concession (V).

Under Phase II of the FTA, Pakistan and China have agreed to eliminate tariffs on no less than $90 \%$ of products, both in terms of tariff lines and trade volume within a reasonable period of time. The second phase will begin after completion of the first phase of tariff elimination/reduction. The period of completion of the second phase is to be negotiated by both countries.

Table-6: Tariff Reduction Modality

\begin{tabular}{clcc}
\hline $\begin{array}{c}\text { Category } \\
\text { No. }\end{array}$ & \multicolumn{1}{c}{ Track } & \multicolumn{2}{c}{ No. of Tariff Lines } \\
\cline { 2 - 4 } Pakistan & China \\
\hline I & Elimination of tariff (Three & 2,423 & 2,681 \\
& years) & $36.60 \%$ & $35.50 \%$ \\
II & 0-5\% (five years) & 1,338 & 2,604 \\
& & $19.90 \%$ & $34.50 \%$ \\
III & Reduction on Margin of & 157 & 604 \\
& Preference of 50\% (five years) & $2 \%$ & $8 \%$ \\
IV & Reduction on Margin of & 1,768 & 529 \\
& Preference of 20\% (five years) & $26.10 \%$ & $7 \%$ \\
V & No Concession & 1,025 & 1,132 \\
& & $15 \%$ & $15 \%$ \\
VI & Exclusion & 92 & - \\
& & $1.40 \%$ & \\
\hline
\end{tabular}

Source: Ministry of Commerce, Government of Pakistan. 
It is important to note that most of the products in Pakistan's Category I ( $0 \%$ tariff) and II (5\% tariff) include machinery, raw materials, and intermediate goods. On the other hand, categories I and II for China consist mostly of finished products. The FTA therefore provides significant opportunities to Pakistani investors to import raw materials and machinery and equipment at lower duties from China and export the finished goods to the expanding market of China under preferential tariffs.

The FTA not only covers trade in goods but also includes provisions for bilateral investment including those related to the promotion and protection of bilateral investment and dispute settlement mechanisms. A key feature of the agreement is the establishment of China-specific investment zones in Pakistan in which Chinese investors shall enjoy fiscal and other incentives. In addition, both countries are negotiating an agreement on trade in services.

In addition to the FTA, both countries have formulated a Joint Program for Comprehensive Economic and Trade Cooperation, under which the two countries shall take further measures in trade promotion and trade facilitation. The Joint Plan envisages moving economic cooperation between the two countries beyond trade to such fields as energy, water conservation and power, transportation, petrochemicals, automobiles, textiles, and telecommunications.

\section{The Gravity Model}

The gravity model has been widely used to measure the impact of trade policy issues such as preferential trade agreements, currency unions, and border trade measures. The model was first introduced by Tinbergen (1962) who used the gravity equation to measure bilateral trade flows in terms of the size of the economy and the geographical distance between the trading partners. Subsequent work has attempted to provide theoretical foundations to the basic gravity model. In particular, Anderson (1979), Bergstrand (1985, 1989), Helpman and Krugman (1985), Frankel and Romer (1999), Anderson and Wincoop (2003), and Helpman (2006) have shown that the gravity model can be derived from a variety of theoretical settings including partial and general equilibrium frameworks.

We follow the approach of Rose (2004) to specify an augmented gravity model that builds on the basic gravity equation to incorporate a variety of factors that are believed to influence bilateral trade follows. The following equation is specified: 


$$
\begin{gathered}
\ln \left(T_{i j}\right)=\alpha_{0}+\alpha_{1} \ln \left(Y_{i} * Y_{j}\right)+\alpha_{2} \ln \left(P C_{i} * P C_{j}\right)+\alpha_{3} \ln \left(K_{i j}\right)+\alpha_{4}\left(B_{i j}\right) \\
+\alpha_{5}\left(t_{i j}\right)+\alpha_{6}\left(F T A_{i j}\right)+\mu
\end{gathered}
$$

Here, $T_{i j}$ is bilateral trade of country $i$ with country $j, Y$ is real GDP, $P C I$ is per-capita income, $\mathrm{K}$ is the distance between country $i$ and country $j, B$ is a dummy variable that is assigned a value of 1 if countries $i$ and $j$ share a common border and a value of 0 otherwise, $t$ is average tariff on bilateral trade between country $i$ and $j$. FTA is a dummy variable that is assigned a value of 1 if country $i$ and country $j$ are signatories (potential or actual) to a bilateral FTA agreement, and $\mu$ is the error term.

The gravity model specifies three types of factors that may influence bilateral trade flows between the two trading partners: (i) the capacity of an economy to export; (ii) the capacity of the economy to absorb imports; and (iii) border and trade measures that may promote or impede bilateral trade flows. The export capacity of the exporting country is measured by GDP, and it is postulated that the higher the GDP, the higher the capacity of an economy to export. Similarly, the GDP of the importing country is viewed as an indicator of the economy to absorb imports with the notion that a higher GDP of the importing country would generate greater demand for imported goods. Per capita GDP represents the levels of income of the exporting and importing countries and it is expected that countries with a higher per capita income would tend to have greater trade volumes. We, therefore, expect positive signs of coefficients $\alpha_{1}$ and $\alpha_{2}$ in the gravity model.

Distance is included as a proxy for transactions costs and it is expected to negatively influence bilateral trade, so the coefficient $\alpha_{3}$ is expected to have a negative sign. Countries that share a common border are likely to have strong bilateral trade relations and hence the coefficient of the dummy variable representing a common border is expected to be positive. Tariffs represent trade costs which will negatively impact the bilateral trade with a negative sign. Finally, a positive sign of the dummy variable representing the Pakistan-China FTA would signify a positive impact of the FTA on bilateral trade flows. The extent to which the FTA might result in trade creation or diversion will be determined by the exponent of the coefficient $\alpha_{6}$. For example, if the coefficient is 0.33 , then the value of $\exp \left(\alpha_{6}\right)$ is 1.39 , and the expansion in trade is estimated to occur by a factor of 1.39 .

\subsection{Data}

The dataset is a balanced panel that includes 25 significant trade partners of Pakistan and China covering the period from 1980 to 2006. Data 
on bilateral trade flows have been collected from IMF's Direction of Trade Statistics. The data on GDP and per-capita income are collected from the World Development Indicators (WDI), whereas data on distance and other geographical measures are taken from CEPII data-sets on geographical and distance datasets. The data on average tariffs have been obtained from the UNCTAD and TRAIN databases. All trade-data in value terms are in millions of US dollars.

\section{Estimation Results}

The gravity model is estimated by pooled Ordinary Least Squares techniques, and the estimated results are reported in Table-7. The reported $\mathrm{R}^{2}$ is 0.711 , indicating that the model has a reasonably good power of explaining variations in trade flows between countries. As expected, GDP is positive and significant implying a direct (positive) relationship between economic size and bilateral trade. Similarly, per capita income is also positive and highly significant, indicating that as the countries grow richer they tend to have a higher level of bilateral trade. In line with the prediction of the gravity model, distance, which is used as proxy for transactions costs, has a significant negative effect on bilateral trade. The positive coefficient of the dummy variable that captures proximity through a common border is also in accord with the gravity hypothesis. However, contrary to expectations, average tariff has a positive sign but it is insignificant.

Of particular interest is the sign of the dummy variable that captures the impact of the FTA between Pakistan and China. The positive and significant coefficient of this variable indicates that the FTA has the potential to enhance bilateral trade between Pakistan and China. More specifically, the model predicts that the bilateral trade between the two countries will expand by a factor of 1.85 . Both countries are likely to gain from the increased volume of bilateral trade resulting from the FTA. In particular, the enhanced volume of trade between the two countries will spur competition in the domestic economies resulting in lower prices for consumers, more product variety and quality, and increased incentives for innovation. By promoting a more efficient allocation of resources, bilateral trade will increase productivity, living standards, and the long-run growth of the two economies. 
Table-7: Gravity Model: Pooled Least Squares Estimates 1980-2006

\begin{tabular}{lcc}
\hline & Dependent Variable: Log (Trade) & \\
\hline Variable & Coefficient & MODEL 2 \\
\hline C & -7.900 & -8.423 \\
LOG (GDP) & $(0.422)$ & $(0.425)$ \\
& $0.559^{*}$ & $0.564^{*}$ \\
LOG (PCI) & $(0.010)$ & $(0.010)$ \\
& $0.343^{*}$ & $0.349^{*}$ \\
LOG (DISTANCE) & $(0.010)$ & $(0.010)$ \\
& $-0.595^{*}$ & $-0.591^{*}$ \\
BORDER & $(0.025)$ & $(0.025)$ \\
& $0.495^{*}$ & $0.516^{*}$ \\
LOG (TARIFF) & $(0.086)$ & $(0.086)$ \\
& 0.121 & 0.200 \\
PAK-CHINA FTA & $(0.109)$ & $(0.109)$ \\
& 0.614 & 0.648 \\
PAK-MALAYSIA FTA & $(0.321)$ & $(0.319)$ \\
& & 1.756 \\
PK-SRI LANKA FTA & & $(0.310)$ \\
R-squared & & 1.606 \\
Adjusted R-squared & & $(0.310)$ \\
Akaike info criterion & 0.000 & 0.715 \\
Schwarz criterion & 4416 & 0.714 \\
Log likelihood & 0.711 & 3.246 \\
F-statistic & 0.711 & 3.260 \\
Prob (F-statistic) & 3.259 & -7159.240 \\
Observations & 3.269 & 1380.212 \\
& -7188.015 & 0.000 \\
& 1807.769 & 4416 \\
\hline
\end{tabular}

This core specification has been extended (see Model 2 in Table-7) to account for Pakistan's FTAs with two other countries, Malaysia and Sri Lanka, both of which are fairly recent developments in Pakistan's trade environment. In this case, GDP, per capita income and border dummy have a significant positive effect on trade flows, while distance has a significant effect. Again, the Pak-China FTA would increase trade between the two countries, as would the Pak-Malaysia and Pak-Sri Lanka FTAs; however, their effect is not as statistically significant as the other variables. 


\section{Trade Specialization Index}

While the gravity model indicates substantial potential for the expansion of bilateral trade as a result of the FTA, it remains to be seen which sectors of Pakistan and China have significant potential for the expansion of bilateral trade. This section examines this issue in terms of the trade specialization index $(\text { TSI })^{1}$ which is defined as:

$$
T S I=\frac{\left(x_{i}-m_{i}\right)}{\left(x_{i}+m_{i}\right)}
$$

where $x_{i}$ and $m_{i}$ respectively denote the exports and imports of the $i^{\text {th }}$ commodity. The index varies between +1 and -1 ; a value closer to +1 signifies an exporter's (Pakistan) comparative advantage and a value closer to -1 implies comparative advantage of the trading partner (China). Table-8 reports the trade specialization indices computed at HS2 commodity classification. It is evident that Pakistan has a comparative advantage in only a narrow range of products (11 products at HS2) including raw materials such as cotton and raw hides and some food products. On the other hand, China has a comparative advantage in a broad range of commodities (84 product categories) (see appendix for a detailed listing). This pattern of comparative advantage is not surprising given the enormous difference between the two countries in terms of economic size and production structure.

It is important to emphasize that, whereas the difference in the pattern of comparative advantage indicates the existence of significant trade complementarities between the two countries and hence a large potential for expansion of bilateral trade, it also indicates that trade between Pakistan and China is likely to be tilted in favor of China at least in the short term. At present, Pakistan's economy lacks diversification and its exports are dominated by textiles and related products. On the other hand, the Chinese economy has achieved much greater diversification and has developed the capacity to export a wide range of manufactured goods from computers and electronic products to machinery and equipment. However, the situation may change in the longer term when the FTA may encourage a shift in production structures that can support a different pattern of bilateral trade than the one predicted on the basis of the existing production structures and trade patterns.

\footnotetext{
${ }^{1}$ See Amable (2000) for details.
} 
Table-8: Trade Specialization Index 2006 - Pakistan versus China - Top 11 Categories

\begin{tabular}{clc}
\hline HS Code & \multicolumn{1}{c}{ Commodity } & TSI \\
\hline 03 & $\begin{array}{l}\text { Fish and crustaceans, mollusks and other aquatic } \\
\text { invertebrates }\end{array}$ & 1.00 \\
01 & Live animals & 1.00 \\
26 & Ores, slag, and ash & 0.99 \\
52 & Cotton & 0.97 \\
41 & Raw hides and skins (other than fur skins) and leather & 0.96 \\
05 & Products of animal origin, not elsewhere specified & 0.95 \\
14 & Vegetable plaiting materials; vegetable products nes & 0.83 \\
13 & Lac; gums, resins and other vegetable saps and extracts & 0.81 \\
78 & Lead and articles thereof & 0.80 \\
11 & Products of milling industry; malt; starches; inulin & 0.41 \\
10 & Cereals & 0.30 \\
\hline
\end{tabular}

Source: Authors' calculations, based on data from the UNCOMTRADE database.

\subsection{Intra-Industry Trade}

Recent decades have witnessed an upsurge in intra-industry trade i.e. trade in similar but differentiated products. Various theoretical arguments have been advanced to explain this phenomenon. According to Grubel and Lloyd (1975), differences in the level of technology and human capital can lead to intra-industry trade even in products with identical factor input requirements. Krugman (1981) emphasizes the role of monopolistic competition and increasing returns to scale in generating intra-industry trade. More precisely, Krugman argues that industries in which increasing returns are achieved at a fairly low level of output can accommodate many producers with each producing a different brand. Under these circumstances, each country will specialize in different varieties of the product and engage in intra-industry trade. Another major reason for increased intra-industry trade is considered to be the growth of regional integration schemes involving crosscountry production sharing arrangements. ${ }^{2}$

${ }^{2}$ Under such arrangements, various stages of the production process for a specific product are undertaken in different countries giving rise to intra-industry trade. 
In view of the importance of intra-industry trade in the context of bilateral and regional cooperation initiatives, it is important to explore the extent of intra-industry trade of the two countries. For this purpose, the Grubel-Lloyd (GL) indices of intra-industry trade have been computed based on the global trading pattern of the two countries. The GL index of intraindustry trade is defined as:

$$
G L-1-\left\{\frac{\left(\left|x_{i}-m_{i}\right|\right)}{\left(x_{i}+m_{i}\right)}\right\}
$$

The GL index varies between and 0 and 1 , where 0 indicates no intra-industry trade and 1 shows a high degree of intra-industry trade.

Table-9 reports the GL indices for both Pakistan and China's top 10 products using their global trade at HS-2 commodity classification ${ }^{3}$. It is clear that intra-industry trade of both countries is quite significant and occurs in a wide range of commodities. For Pakistan, among the top commodity groups with significant intra-industry trade are articles of stone, plaster and cement, furniture and bedding, manmade filaments, tools, implements and cutlery, special woven fabrics, and optical equipment. In contrast, the intra-industry trade of China takes place in an extensive range of commodities from plastering materials to pharmaceutical products and from machinery and mechanical appliances to photographic equipment. There is, therefore, considerable potential for expanding intra-industry trade between the two countries.

\footnotetext{
${ }^{3}$ A more detailed listing of all product categories (HS2) can be obtained from the authors on request.
} 
Table-9: Grubel-Lloyd Index of Intra-Industry Trade - 2005

\begin{tabular}{|c|c|c|c|}
\hline $\begin{array}{l}\text { HS } \\
\text { Code } \\
\end{array}$ & Commodity & Pakistan & China \\
\hline 68 & $\begin{array}{l}\text { Articles of stone, plaster, cement, asbestos, mica or } \\
\text { similar materials }\end{array}$ & 0.97 & 0.33 \\
\hline 94 & $\begin{array}{l}\text { Furniture; bedding, mattresses, cushions and } \\
\text { similar stuffed furnishing }\end{array}$ & 0.97 & 0.07 \\
\hline 54 & Manmade filaments & 0.95 & 0.78 \\
\hline 06 & Live trees and other plants; & 0.89 & 0.94 \\
\hline 82 & $\begin{array}{l}\text { Tools, implements, cutlery, spoons and forks, of } \\
\text { base metal }\end{array}$ & 0.88 & 0.47 \\
\hline 20 & Preparations of vegetables, fruit or nuts & 0.88 & 0.10 \\
\hline 01 & Live animals & 0.85 & 0.50 \\
\hline 08 & Edible fruit and nuts; peel of citrus fruit or melons & 0.85 & 0.76 \\
\hline 04 & Dairy produce; birds eggs; natural honey; & 0.81 & 0.73 \\
\hline 97 & Works of art, collectors' pieces and antiques & 0.80 & 0.27 \\
\hline 44 & Wood and articles of wood; wood charcoal & 0.37 & 0.94 \\
\hline 06 & Live trees and other plants; & 0.89 & 0.94 \\
\hline 37 & Photographic or cinematographic goods & 0.09 & 0.95 \\
\hline 17 & Sugars and sugar confectionery & 0.36 & 0.96 \\
\hline 11 & $\begin{array}{l}\text { Products of the milling industry; malt; starches; } \\
\text { inulin }\end{array}$ & 0.40 & 0.96 \\
\hline 52 & Cotton & 0.26 & 0.98 \\
\hline 85 & $\begin{array}{l}\text { Electrical machinery and equipment and parts } \\
\text { thereof; sound recorders and recording equipment. }\end{array}$ & 0.08 & 0.99 \\
\hline 40 & Rubber and articles thereof & 0.20 & 0.99 \\
\hline 10 & Cereals & 0.26 & 0.99 \\
\hline 25 & Salt; sulfur; earths and stone; plastering materials & 0.62 & 1.00 \\
\hline
\end{tabular}

Source: Authors' calculations, based on data taken from the UN COMTRADE database.

The above indices are based on the global trade of the two countries. It is instructive to look also at the GL indices ${ }^{4}$ based on the bilateral trade between the two countries (Table-10)' . Among the major commodity groups where significant intra-industry trade has taken place on

\footnotetext{
4 These indices are simply obtained by subtracting the absolute values of the trade specialization index from 1 .

${ }^{5}$ GL Indices for all HS2 commodities can be obtained from the authors on request.
} 
a bilateral basis are copper, food products, tools and cutlery, and carpets and floor coverings.

Table-10: Bilateral GL Index 2006 - Top 20 Product Categories

\begin{tabular}{clc}
\hline HS & \multicolumn{1}{c}{ Commodity } & $\begin{array}{c}\text { GL } \\
\text { Index }\end{array}$ \\
\hline 74 & Copper and articles thereof & 0.964 \\
08 & Edible fruit and nuts; peel of citrus fruit or melons & 0.847 \\
10 & Cereals & 0.700 \\
11 & Products of the milling industry; malt; starches; inulin & 0.585 \\
82 & Tools, implements, cutlery, spoons and forks, of base metal & 0.562 \\
25 & Salt; sulfur; earths and stone; plastering materials & 0.545 \\
12 & Oil seeds and oleaginous fruits & 0.461 \\
68 & Articles of stone, plaster, cement, asbestos, mica or similar & 0.426 \\
& materials & 0.388 \\
42 & Articles of leather; saddlery and harness & 0.292 \\
57 & Carpets and other textile floor coverings & 0.268 \\
29 & Organic chemicals & 0.222 \\
92 & Musical instruments; parts and accessories of such articles \\
53 & Other vegetable textile fibers; paper yarn and woven fabric & 0.214 \\
& of paper yarn & \\
78 & Lead and articles thereof & 0.196 \\
13 & Lac; gums, resins and other vegetable saps and extracts & 0.190 \\
61 & $\begin{array}{l}\text { Articles of apparel and clothing accessories, knitted or } \\
\text { crocheted }\end{array}$ & 0.184 \\
02 & Meat and edible meat offal & 0.177 \\
14 & Vegetable plaiting materials; vegetable products nes & 0.165 \\
62 & $\begin{array}{l}\text { Articles of apparel and clothing accessories, not knitted or } \\
\text { crocheted }\end{array}$ & 0.149 \\
51 & $\begin{array}{l}\text { Wool, fine or coarse animal hair; horsehair yarn and woven } \\
\text { fabric }\end{array}$ & 0.129 \\
\hline & & \\
\hline
\end{tabular}

Source: Authors' calculations, based on data taken from the UN COMTRADE database.

Intra-industry trade can play a pivotal role in promoting bilateral economic cooperation between Pakistan and China. This is because this type of trade can flourish even in situations where the trade and production structures of the trading partners lack strong complementarities. In this 
scenario, Pakistan and China can strengthen their trade linkages by devising mechanisms to promote intra-industry trade. One way to accomplish this is through bilateral production sharing arrangements that involve the initiation of part of a manufacturing process for specific good in one country and the transfer of the activity to the other country for further processing. According to Yeats (1998), production sharing arrangements have contributed to a high level of intra-industry trade within various regional trading blocs. In the same manner, both Pakistan and China can achieve greater economic integration by helping to evolve a vertically integrated production structure in sectors that are of economic significance in the bilateral context. Some of the potential areas where regional production sharing systems can be developed are leather products, textiles and clothing, and light engineering. Such arrangements would allow the two countries to specialize in different production processes within a particular industry and thus achieve benefits of specialization and scale economies.

\section{Concluding Remarks}

This paper has explored the prospects of bilateral trade between Pakistan and China especially in the context of recently signed free trade agreement between the two countries. Employing an augmented gravity model of bilateral trade flows, it is shown that there is a great potential for expansion of bilateral trade between the two countries as a result of the FTA. Taking the analysis further, the paper has examined the pattern of bilateral trade in terms of the two widely used trade indices i.e. the trade specialization index, and the Gruble-Lloyd index of intra-industry trade. Based on this analysis, the paper argues that while there is substantial potential for expansion of bilateral trade between the two countries, trade is likely to be heavily tilted in favor of China, at least in the short term. From a longer-term perspective, however, the FTA is likely to influence a change in the production structures that may support a more balanced level of bilateral trade between the two countries. There is thus a potential for both countries to gain from an enhanced level of trade between the two countries that will spur competition in the domestic economies resulting in lower prices for consumers, more product variety and quality, and increased incentives for innovation. By promoting a more efficient allocation of resources, bilateral trade will help increase the productivity, living standards, and long-run growth of the two economies. 


\section{References}

Amable, B. (2000). International Specialization and Growth. Structural Change and Economic Dynamics, 11 : 413-431.

Anderson J.E. (1979). A Theoretical Foundation for the Gravity Equation. American Economic Review, 69(1), 106-116.

Anderson, J., and Wincoop, E.V. (2003). Gravity with Gravitas: A Solution to the Border Puzzl. American Economic Review, 93, 170-192

Bergstrand, J.H. (1985). The Gravity Equation in International Trade: Some Microeconomic Foundations and Empirical Evidence. The Review of Economics and Statistics, Elsevier Science Publishers BV (NorthHolland), 474-481.

Bergstrand, J.H. (1989). The Generalized Gravity Equation, Monopolistic Competition, and the Factor Proportions Theory in International Trade. Review of Economics and Statistics, 71 (1), 143-53.

Centre d'Études Prospectives et d'Informations Internationales (CEPII) website, http://www.cepii.fr/anglaisgraph/bdd/distances.html.

Frankel and Romer (1999). Does Trade Cause Growth? The American Economic Review, 89(3).

Grossman, G., and Helpman, E. (1991). Innovation and Growth in the World Economy. MIT Press, Cambridge M.A.

Grubel and Lloyd (1975). Intra-industry Trade: The Theory and Measurement of International Trade in Differentiated Products. Macmillan.

Helpman, E. (2006). Trade, FDI, and the Organization of Firms. Journal of Economic Literature, American Economic Association Publications, 44 : 589-630.

Helpman, E., \& Krugman, P. (1985). Market structure and Foreign Trade. MIT Press Cambridge: Mass.

International Monetary Fund. Direction of Trade Statistics, IMF, Washington D.C. 
Krugman, P. (1981). Intra-Industry Specialization and the Gains from Trade. The Journal of Political Economy, 89 : 959-973

Rose, A.K. (2004). Do We Really Know That the WTO Increases Trade? The American Economic Review, American Economic Association, 94 : 98-114.

The World Bank. WITS Database.

Tinbergen, J. (1962). Shaping the World Economy: Suggestions for an International Economic Policy. New York, Twentieth Century Fund.

UNCOMTRADE Database website, http://comtrade.un.org/db/)

Yeats (1998). Just How Big is Global Production Sharing? World Bank, Development Research Group. 
Appendix

Table-A.5: Trade Specialization Index - All Commodities in 2006

\begin{tabular}{|c|c|c|}
\hline $\begin{array}{l}\text { HS } \\
\text { Code }\end{array}$ & Commodity & TSI \\
\hline 03 & Fish and crustaceans, molluscs \& other aquatic invertebrates & 1.00 \\
\hline 01 & Live animals & 1.00 \\
\hline 26 & Ores, slag and ash & 0.99 \\
\hline 52 & Cotton & 0.97 \\
\hline 41 & Raw hides and skins (other than fur skins) and leather & 0.96 \\
\hline 05 & Products of animal origin, not elsewhere specified & 0.95 \\
\hline 14 & Vegetable plaiting materials; vegetable products nes & 0.83 \\
\hline 13 & Lac; gums, resins and other vegetable saps and extracts & 0.81 \\
\hline 78 & Lead and articles thereof & 0.80 \\
\hline 11 & Products of the milling industry; malt; starches; inulin & 0.41 \\
\hline 10 & Cereals & 0.30 \\
\hline 74 & Copper and articles thereof & -0.04 \\
\hline 08 & Edible fruit and nuts; peel of citrus fruit or melons & -0.15 \\
\hline 82 & Tools, implements, cutlery, spoons and forks, of base metal & -0.44 \\
\hline 25 & Salt; sulfur; earths and stone; plastering materials & -0.45 \\
\hline 12 & Oil seeds and oleaginous fruits & -0.54 \\
\hline 68 & $\begin{array}{l}\text { Articles of stone, plaster, cement, asbestos, mica or similar } \\
\text { materials }\end{array}$ & -0.57 \\
\hline 42 & Articles of leather; saddlery and harness & -0.61 \\
\hline 57 & Carpets and other textile floor coverings & -0.71 \\
\hline 29 & Organic chemicals & -0.73 \\
\hline 92 & Musical instruments; parts and accessories of such articles & -0.78 \\
\hline 53 & $\begin{array}{l}\text { Other vegetable textile fibers; paper yarn and woven fabric of } \\
\text { paper yarn }\end{array}$ & -0.79 \\
\hline 61 & Articles of apparel and clothing accessories, knitted or crocheted & -0.82 \\
\hline
\end{tabular}


2 Meat and edible meat offal $\quad-0.82$

62 Articles of appare1 and clothing accessories, not knitted or $\quad-0.85$ crocheted

51 Wool, fine or coarse animal hair; horsehair yarn and woven $\quad-0.87$ fabric

39 Plastics and articles thereof $\quad-0.90$

71 Natural or cultured pearls, precious or semi-precious stones -0.92

36 Explosives; pyrotechnic products; matches $\quad-0.92$

20 Preparations of vegetables, fruit or nuts -0.93

63 Other made up textile articles; sets; worn clothing and worn -0.93 textile articles ...

90 Optical, photographic, cinematographic, measuring, checking, -0.93 precision, med ...

95 Toys, games and sports requisites; parts and accessories thereof -0.93

27 Mineral fuels, mineral oils and products of their distillation $\quad-0.94$

30 Pharmaceutical products $\quad-0.95$

76 Aluminum and articles thereof -0.95

55 Man-made staple fibers $\quad-0.95$

72 Iron and steel $\quad-0.96$

60 Knitted or crocheted fabrics $\quad-0.96$

18 Cocoa and cocoa preparations $\quad-0.96$

99 Commodities not specified according to kind $\quad-0.96$

70 Glass and glassware $\quad-0.97$

59 Impregnated, coated, covered or laminated textile fabrics $\quad-0.97$

56 Wadding, felt and non-wovens; special yarns, twine, cordage, $\quad-0.97$ ropes and cable ...

21 Miscellaneous edible preparations $\quad-0.97$

96 Miscellaneous manufactured articles $\quad-0.97$

73 Articles of iron or steel -0.98

07 Edible vegetables and certain roots and tubers $\quad-0.98$

40 Rubber and articles thereof $\quad-0.99$ 
54 Man-made filaments

32 Tanning or dyeing extracts

94 Furniture; bedding, mattresses, cushions and similar stuffed $\quad-0.99$ furnishing

58 Special woven fabrics; tufted textile fabrics; lace, tapestries; $\quad-0.99$ trimmings; ...

19 Preparations of cereals, flour, starch or milk; bakers' wares $\quad-0.99$

87 Vehicles other than railway or tramway rolling stock $\quad-0.99$

69 Ceramic products $\quad-1.00$

84 Machinery and mechanical appliances; parts thereof $\quad-1.00$

48 Paper and paperboard; articles of paper pulp, of paper or of $\quad-1.00$ paperboard

49 Printed books, newspapers, pictures and other products of the -1.00 printing industry ...

28 Inorganic chemicals $\quad-1.00$

44 Wood and articles of wood; wood charcoal $\quad-1.00$

65 Headgear and parts thereof $\quad-1.00$

38 Miscellaneous chemical products $\quad-1.00$

64 Footwear, gaiters and the like; parts of such articles $\quad-1.00$

17 Sugars and sugar confectionery $\quad-1.00$

33 Essential oils and resinoids; perfumery, cosmetic or toilet $\quad-1.00$ preparations

89 Ships, boats and floating structures $\quad-1.00$

34 Soap, organic surface-active agents $\quad-1.00$

85 Electrical machinery and equipment and parts thereof; sound -1.00 recorders and receivers

50 Silk $\quad-1.00$

04 Dairy produce; birds eggs; natural honey; $\quad-1.00$

06 Live trees and other plants; $\quad-1.00$

09 Coffee, tea, mat and spices $\quad-1.00$

15 Animal or vegetable fats and oils $\quad-1.00$ 
22 Beverages, spirits and vinegar $\quad-1.00$

23 Residues and waste from the food industries -1.00

24 Tobacco and manufactured tobacco substitutes $\quad-1.00$

31 Fertilizers $\quad-1.00$

35 Albuminoidal substances; modified starches; glues; enzymes $\quad-1.00$

37 Photographic or cinematographic goods $\quad-1.00$

43 Fur skins and artificial fur; manufactures thereof $\quad-1.00$

45 Cork and articles of cork $\quad-1.00$

46 Manufactures of straw, of esparto or of other plaiting materials -1.00

47 Pulp of wood or of other fibrous cellulose material -1.00

66 Umbrellas, sun umbrellas, walking sticks, seat sticks, whips, $\quad-1.00$ riding-crops

67 Prepared feathers and down and articles made of feathers or of -1.00 down

75 Nickel and articles thereof $\quad-1.00$

79 Zinc and articles thereof $\quad-1.00$

80 Tin and articles thereof $\quad-1.00$

81 Other base metals; cermets; articles thereof -1.00

83 Miscellaneous articles of base metal -1.00

86 Railway or tramway locomotives, rolling-stock and parts $\quad-1.00$ thereof

88 Aircraft, spacecraft, and parts thereof $\quad-1.00$

91 Clocks and watches and parts thereof -1.00

93 Arms and ammunition; parts and accessories thereof $\quad-1.00$

97 Works of art, collectors' pieces and antiques $\quad-1.00$

Source: Authors' calculations, based on data taken from the UN COMTRADE database. 